\title{
Association of S100B Serum Levels with Metabolic Syndrome and its Components
}

\section{Associação dos Níveis de Soro S100B com a Síndrome Metabólica e seus Componentes}

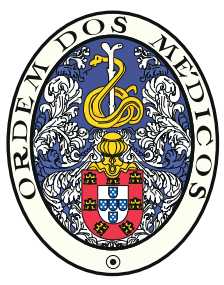

Sorayya KHEIROURI ${ }^{1}$, Elham EBRAHIMI ${ }^{1}$, Mohammad ALIZADEH $\bowtie 1$
Acta Med Port 2018 Apr;31(4):201-206 - $\underline{\text { https://doi.org/10.20344/amp.9073 }}$

ABSTRACT

Introduction: We aimed to compare serum levels of S100B between patients with metabolic syndrome and healthy subjects and to investigate the association of S100B with components of the metabolic syndrome.

Materials and Methods: In this study, 44 patients with metabolic syndrome and 44 healthy subjects participated. The participants' body mass index, waist circumference, systolic and diastolic blood pressure were measured. Serum levels of low and high density lipoprotein cholesterol, total cholesterol, triglyceride, fasting blood glucose, insulin, S100B protein were determined by enzymatic and ELISA methods.

Results: The participants with metabolic syndrome had significantly higher levels of S100B than those in the control group ( $p<0.0001)$. Serum levels of $\mathrm{S} 100 \mathrm{~B}$ protein were positively correlated with abdominal obesity (rho $=0.26 ; p=0.01$ ) and serum levels of triglyceride (rho $=0.26 ; p=0.01$ ). Moreover, serum levels of S100B were higher in subjects with abdominal obesity $(p=0.02)$, with higher serum triglyceride levels $(p=0.03)$ and with hypertension $(p=0.01)$.

Conclusion: The findings indicate that there may be a link between S100B protein with abdominal obesity and serum levels of triglycerides. This warrants further research to elucidate whether increased S100B levels in patients with metabolic syndrome are involved in the pathogenesis of cardiovascular disorders.

Keywords: Metabolic Syndrome; Obesity, Abdominal; S100 Calcium Binding Protein beta Subunit

\section{RESUMO}

Introdução: O nosso objetivo foi comparar os níveis séricos de S100B entre pacientes com síndrome metabólica e indivíduos saudáveis e investigar a associação de S100B com os componentes da síndrome metabólica.

Materiais e Métodos: Neste estudo participaram 44 pacientes com síndrome metabólica e 44 indivíduos saudáveis. Foram medidos o índice de massa corporal, o perímetro abdominal, pressão arterial sistólica e diastólica dos participantes. Os níveis séricos de colesterol de lipoproteínas de baixa e alta densidade, colesterol total, triglicerídos, glicemia em jejum, insulina, proteína S100B foram determinados por métodos enzimáticos e ELISA.

Resultados: Os participantes com síndrome metabólica apresentaram níveis significativamente mais altos de S100B do que os do grupo de controlo $(p<0,0001)$. Os níveis séricos de proteína S100B foram positivamente correlacionados com obesidade abdominal (rho $=0,26 ; p=0,01$ ) e níveis séricos de triglicéridos ( $r h o=0,26 ; p=0,01$ ). Além disso, os níveis séricos de $\mathrm{S} 100 \mathrm{~B}$ foram mais elevados em indivíduos com obesidade abdominal $(p=0,02)$, com níveis mais elevados de triglicéridos no soro $(p=0,03)$ e com hipertensão $(p=0,01)$.

Conclusão: Os resultados indicam que pode haver uma ligação entre a proteína S100B com obesidade e níveis séricos de triglicéridos. Isso implica a necessidade de mais estudos para elucidar se o aumento dos níveis de S100B em pacientes com síndrome metabólica está envolvido na patogénese de doenças cardiovasculares.

Palavras-chave: Obesidade Abdominal; Síndrome Metabólica; Subunidade beta da Proteína Ligante de Cálcio S100

\section{INTRODUCTION}

$\mathrm{S} 100$ calcium-binding protein $\mathrm{B}(\mathrm{S} 100 \mathrm{~B})$ is a small $21 \mathrm{kDa}$ (dimer form) secretory protein which belongs to the S-100 protein family. It was primarily derived from astrocytes and has various intra and extracellular biological roles. However, subsequent research has suggested that adipose tissue is a major source of serum S100B. ${ }^{1}$ Concentration of S100B in adipose tissue is comparable with its content in nervous tissue. ${ }^{2}$ Among different cell types of adipose tissue, mature adipocytes possess the highest levels of S100B. ${ }^{3}$ Moreover, elevated S100B expression has been reported in plasma and adipocyte-enriched fraction of adipose tissue of obese animals. ${ }^{4}$

Nutritional, metabolic and anthropometric status have recently been suggested as important factors affecting serum levels of the S100B. ${ }^{5-9}$ It has been shown that serum levels of $\mathrm{S} 100 \mathrm{~B}$ decrease during chronic fasting and normalize with weight gain. ${ }^{7}$ Steiner et al reported that S100B serum levels are strongly associated with body mass index (BMI) and reflect excess adipose tissue mass. ${ }^{10}$ Adipocyte derived $\mathrm{S} 100 \mathrm{~B}$ is strongly related to the arrangement of cellular energy metabolism and up-regulation of S100B has been attributed to metabolic disturbances including changes in glucose metabolism. ${ }^{6} \mathrm{~A}$ close association has been indicated between increased S100B levels with insulin resistance ${ }^{6}$ and visceral obesity. ${ }^{8}$ Increased S100B level has also been reported in hypertensive patients. ${ }^{9}$ Most of these indicators have been defined as features of metabolic syndrome (MetS).

Themetabolicsyndromeischaracterizedbyacombination of conditions including central obesity, dyslipidemia, high

1. Department of Nutrition. Tabriz University of Medical Sciences. Tabriz. Iran.

$\triangle$ Autor correspondente: Mohammad Alizadeh. mdalizadeh@tbzmed.ac.ir

Recebido: 12 de abril de 2017 - Aceite: 06 de fevereiro de 2018 | Copyright $\odot$ Ordem dos Médicos 2018 
blood pressure and impaired fasting blood glucose (FBG). A MetS event has been reported as one of the outcomes of adipose tissue dysfunction. ${ }^{11-13}$ Moreover, impaired adipose tissue function is accompanied by abnormalities in lipid metabolism including hypertriglyceridemia, low high-density lipoprotein cholesterol levels ${ }^{14}$ and hypertension, ${ }^{15}$ all related with a higher risk for the development of MetS. Besides, adipose tissue dysfunction goes along through changes in serum S100B levels. ${ }^{4}$ Therefore, a link between MetS and serum levels of S100B has been proposed but conclusive evidence is missing. We aimed to investigate serum levels of S100B in probands with MetS without a prior history of psychiatric or neurological disorders and also to study the connection of S100B with components of MetS.

\section{MATERIALS AND METHODS \\ Participants}

Eighty eight adult volunteers (aged 30 - 50 years) were recruited from a medical weight loss center using convenience sampling method. A power calculation based on mean \pm SD of S100B protein from previously published data, ${ }^{16}$ with $5 \%$ significance level test $(\alpha=0.05)$, power of $90 \%$ ( $\beta=0.1$ ), accounting $20 \%$ expected dropouts suggested a sample size of 44 in each group. According to the ATP (III) criteria, 44 of the participants (20 male and 24 female) had MetS and another 44 healthy individuals (23 male and 21 female) served as the control group. A written informed consent was obtained from each subject. The study was approved by the Ethical Committee of Tabriz University of Medical Sciences, Tabriz, Iran (Ref. no. TBZMED.REC.1394.345).

Inclusion criteria for MetS group comprised having at least 3 of 5 ATP (III) criteria as follows: abdominal obesity, given as waist circumference (WC) $>88 \mathrm{~cm}$ for women and $>102$ for men, serum triglyceride $(T G) \geq 150 \mathrm{mg} / \mathrm{dL}$, high-density lipoprotein cholesterol (HDL-c) $<50 \mathrm{mg} / \mathrm{dL}$ for women and $<40 \mathrm{mg} / \mathrm{dL}$ for men, blood pressure $\geq 130 / 85$ $\mathrm{mm} \mathrm{Hg}$, fasting blood glucose $(\mathrm{FBG}) \geq 100 \mathrm{mg} / \mathrm{dL}$. Exclusion criteria were body mass index $(B M I) \geq 40 \mathrm{~kg} / \mathrm{m}^{2}$, infectious or chronic inflammatory diseases, history of psychiatric diseases, receiving anti-obesity, anti-inflammatory or antihypertensive medications, thyroid disorders, endocrine diseases, smoking, excessive consumption of alcohol, pregnancy and lactating, menopause and diet therapy during three months prior to the study.

The subjects' anthropometry parameters including body weight, height and waist circumference (WC) were measured and BMI was calculated. Finally, systolic and diastolic blood pressure (SBP and DBP, respectively) was measured.

\section{Biochemical assessments}

After an overnight fasting, five $\mathrm{ml}$ of venous blood was collected and serum were separated and stored at $-70^{\circ} \mathrm{C}$ until analysis.

The levels of serum total cholesterol (TC), HDL-C and TG were measured by enzymatic colorimetric methods.
Serum LDL-c was calculated by Friedewald equation. Fasting blood sugar were determined by the glucose oxidase method. Insulin levels were determined by insulin ELISA method and the homeostasis model assessment (HOMA-IR)- insulin sensitivity was calculated.

S100B levels were measured by the ELISA method according to the protocol provided by the manufactures (Eastbiopharm CO., LTD).

\section{Statistical analyses}

Normally distributed data were summarized by mean \pm standard deviation (SD) and the differences between the two groups were assessed by independent sample t-test. Nonparametric variables were presented as median (percentile 25, 75) and their differences between two groups were assessed by Mann-Whitney $U$ test. Spearman's coefficient test was used to assess the correlation between S100B with measured variables. Data analysis was performed by SPSS 16 Software and $p$ values less than 0.05 were considered as statistically significant.

\section{RESULTS}

\section{Demographic characteristics}

There was no significant difference in age between the groups (Table 1). As expected, mean body weight, WC and $\mathrm{BMI}$ were significantly higher in MetS group as compared with control group (all $p<0.0001$ ). The participants with MetS had higher systolic (non- significant, $p=0.06$ ) and diastolic $(p=0.01)$ blood pressure than the controls. Serum concentrations of TC, TG, LDL-C, FBG, insulin, HOMA-IR were significantly higher and HDL-c lower in the MetS group than the control group (Table 1).

\section{Serum levels of S100B and its association with components of MetS}

As shown in Fig. 1, the participants with MetS had significantly higher levels of S100B [59.91 (35.30, 97.36) $\mathrm{pg} / \mathrm{mL}]$ than those in the control group [17.12 $(0.00,47.07)$ $\mathrm{pg} / \mathrm{mL}](p<0.0001)$. Serum levels of $\mathrm{S} 100 \mathrm{~B}$ protein positively correlated with WC (rho $=0.26 ; p=0.01$ ) and serum levels of TG (rho $=0.26 ; p=0.01$ ), but was not significantly correlated with HDL-C, FBG, SBP and DBP (Table 2). As shown in Table 3, subjects with abdominal obesity had higher serum levels of S100B ( $p=0.02)$, with serum TG levels $\geq 150$ than those with $<150(p=0.03)$ and also among those with hypertension as compared with normotensive individuals $(p=0.01)$.

\section{Association of $\mathrm{S} 100 \mathrm{~B}$ protein with demographic, anthropometric and metabolic parameters}

As shown in Table 4, serum levels of S100B protein did not significantly correlate with age, gender, BMI, serum levels of insulin, insulin resistance, TC and LDL-c levels.

\section{DISCUSSION}

In the present study, patients with MetS had higher levels of $\mathrm{S} 100 \mathrm{~B}$ than those in the control group and 
Table 1 - Demographic characteristics and serum metabolic parameters of the studied groups

\begin{tabular}{lccc}
\hline & $\begin{array}{c}\text { Patients } \\
(\mathrm{n}=44)\end{array}$ & $\begin{array}{c}\text { Controls } \\
(\mathrm{n}=44)\end{array}$ & $p$ value \\
\hline Age $(\mathrm{year})$ & $41.39 \pm 7.08$ & $38.64 \pm 5.77$ & $0.05^{*}$ \\
BMI $\left(\mathrm{kg} / \mathrm{m}^{2}\right)$ & $32.67 \pm 4.02$ & $26.47 \pm 4.34$ & $<0.0001^{*}$ \\
WC $(\mathrm{cm})$ & $109.10 \pm 11.94$ & $88.82 \pm 11.65$ & $<0.0001^{*}$ \\
SBP $(\mathrm{mmHg})$ & $124.27 \pm 17.32$ & $117.64 \pm 14.86$ & $0.06^{*}$ \\
DBP $(\mathrm{mmHg})$ & $82.04 \pm 12.07$ & $77.20 \pm 9.50$ & $0.01^{*}$ \\
TC $(\mathrm{mg} / \mathrm{dL})$ & $204.50 \pm 37.79$ & $174.34 \pm 39.04$ & $<0.0001^{*}$ \\
TG $(\mathrm{mg} / \mathrm{dL})$ & $234.20 \pm 97.53$ & $127.14 \pm 62.67$ & $<0.0001^{*}$ \\
LDL-c $(\mathrm{mg} / \mathrm{dL})$ & $118.56 \pm 32.40$ & $104.11 \pm 35.60$ & $0.05^{*}$ \\
HDL-c $(\mathrm{mg} / \mathrm{dlL})$ & $39.09 \pm 7.41$ & $44.79 \pm 11.15$ & $0.006^{*}$ \\
FBG $(\mathrm{mg} / \mathrm{dL})$ & $111.61 \pm 26.26$ & $87.95 \pm 11.53$ & $<0.0001^{*}$ \\
Insulin (mU/L) & $0.81(0.74,0.92)$ & $0.74(0.69,0.77)$ & $<0.0001^{\dagger}$ \\
HOMA-IR & $23.50(21.25,26.755)$ & $21.00(20.00,22.00)$ & $<0.0001^{\dagger}$ \\
\hline
\end{tabular}

BMI: body mass index; WC: waist circumference; SBP: systolic blood pressure; DBP: diastolic blood pressure; TC: total cholesterol; TG: triglyceride; LDL-C: low density lipoprotein cholesterol; HDL-C: high density lipoprotein cholesterol; FBG: fasting blood glucose; HOMA-IR: homeostatic model assessment- insulin resistance.

All data were expressed as mean $\pm \mathrm{SD}$, except insulin and HOMA-IR which were expressed as median (percentile 25,75 ). * $p$ values were reported based on independent samples $t$ - test. $\dagger p$ values were reported based on Mann-Whitney $U$ test.

circulating S100B levels were positively correlated with abdominal obesity. Few researchers have studied S100B levels in metabolic diseases. Enhanced circulating levels of $\mathrm{S} 100 \mathrm{~B}$ have been mostly reported in neuropsychiatric disorders including schizophrenia, ${ }^{6}$ Parkinson's disease ${ }^{17}$ depression, ${ }^{18}$ Alzheimer's disease ${ }^{19}$ and it is ascribed to glial pathologies. According to evidences, adipose tissue mass seems to be alternatively accountable. In animal models, increased white adipose tissue S100B gene expression and also enhanced plasma levels of S100B related to obesity have been reported by Buckman et al. ${ }^{4}$ Elevated serum levels of S100B have also been observed in obese individuals with obstructive sleep apnea-hypopnea syndrome. ${ }^{20,21}$ O'Connell et al in a study on schizophrenia patients have indicated that female subjects, not male patients, had higher serum levels of S100B compared to controls which was positively correlated with BMI. ${ }^{22}$ Steiner et al have demonstrated that up regulated S100B serum

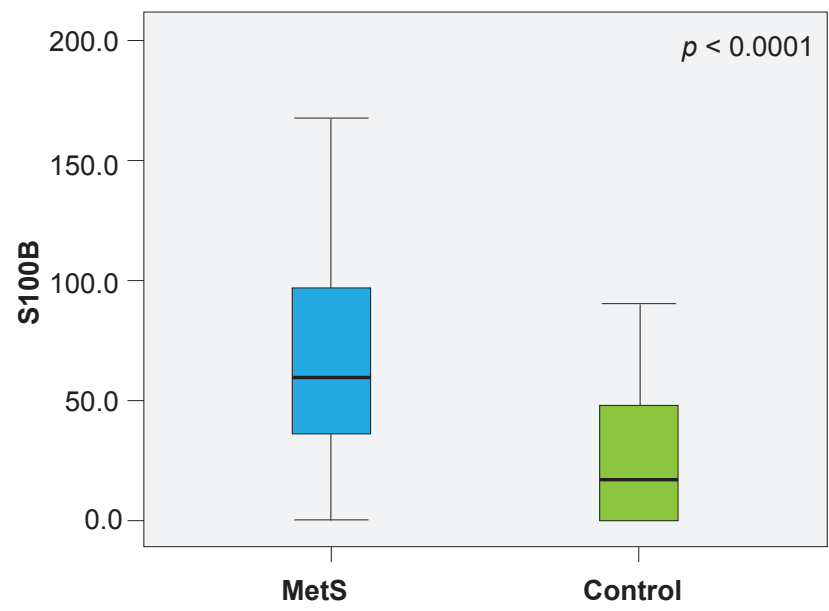

Figure 1 - Serum S100B levels $(p g / m L)$ in MetS $(n=44)$ and control $(n=44)$ groups levels in schizophrenia is associated with abdominal obesity and insulin resistance. ${ }^{8}$ Taken all together, it appears that adipose tissue mass might be determinant of serum $\mathrm{S} 100 \mathrm{~B}$ levels. Astrocytes dysfunction is another possibility to explain increased S100B serum levels in patients with MetS. It has been shown that astrocytic process plasticity is crucial for the central modulation of metabolic status via management of extracellular neurotransmitter levels. ${ }^{23}$ Astrocytic plasticity is impaired by chronic overnutrition or metabolic inflammation. Inflamed astrocytes lead to metabolic imbalance and thus MetS. ${ }^{23}$ However, further research is needed to differentiate the effect of adipose tissue mass and astrocytes on serum S100B level.

In this study, a direct relationship was also noticed between S100B and serum levels of TG. We also observed that serum S100B levels were higher in individuals with TG levels equal or greater than $150 \mathrm{mg} / \mathrm{dL}$. There is apparently lack of evidence regarding the connection between S100B and TG. Nevertheless, according to previous investigations, it is proposed that $\mathrm{S} 100 \mathrm{~B}$ increases $\mathrm{TG}$ level through involvement in lipolysis. ${ }^{24}$ Higher circulating levels of lipolysis controlling hormones (including glucagon, adrenaline, isoproterenol, norepinephrine, ACTH, and dibutyryl cyclic AMP) have been indicated in patients with

Table 2 - Spearman's correlation of serum levels of S100B protein with components of MetS

\begin{tabular}{lcc}
\hline & \multicolumn{2}{c}{ S100B } \\
\hline SBP & Spearman's rho & $p$ value \\
DBP & 0.07 & 0.51 \\
TG & 0.18 & 0.09 \\
HDL-C & 0.26 & 0.01 \\
FBG & -0.16 & 0.13 \\
WC & 0.11 & 0.31 \\
\hline
\end{tabular}

SBP: systolic blood pressure; DBP: diastolic blood pressure; TG: triglyceride; HDL-c: high density lipoprotein cholesterol; FBG: fasting blood glucose; WC: waist circumference 
Table 3 - Serum S100B level $(\mathrm{pg} / \mathrm{mL})$ based on components of MetS according to ATP (III) criteria

\begin{tabular}{|c|c|c|}
\hline \multicolumn{3}{|c|}{ Abdominal obesity ${ }^{\mathrm{a}}(\mathrm{cm})$} \\
\hline Yes $(n=46)$ & $55.82 \pm 4.29$ & \multirow[t]{2}{*}{$p=0.02$} \\
\hline No $(n=41)$ & $40.81 \pm 5.15$ & \\
\hline \multicolumn{3}{|l|}{ TG (mg/dL) } \\
\hline$\geq 150(n=46)$ & $58.70 \pm 7.66$ & \multirow{2}{*}{$p=0.03$} \\
\hline$<150(n=41)$ & $37.58 \pm 6.19$ & \\
\hline \multicolumn{3}{|c|}{ Blood pressure $^{\mathrm{b}}(\mathrm{mmHg})$} \\
\hline Unfavorable $(n=26)$ & $66.99 \pm 9.72$ & \multirow{2}{*}{$p=0.01$} \\
\hline Favorable $(n=61)$ & $40.97 \pm 5.73$ & \\
\hline \multicolumn{3}{|l|}{ FBG (mg/dL) } \\
\hline$\geq 100(n=34)$ & $54.50 \pm 8.06$ & \multirow{2}{*}{$p=0.26$} \\
\hline$<100(\mathrm{n}=53)$ & $45.05 \pm 6.58$ & \\
\hline \multicolumn{3}{|l|}{ HDL-c ${ }^{d}(\mathrm{mg} / \mathrm{dL})$} \\
\hline Unfavorable $(n=54)$ & $57.76 \pm 6.91$ & \multirow{2}{*}{$p=0.15$} \\
\hline Favorable $(n=33)$ & $38.90 \pm 7.04$ & \\
\hline
\end{tabular}

Data were expressed as mean \pm SE. $p$ values are based on Mann-Whitney $U$ test. FBG: fasting blood glucose; TG: triglyceride; HDL-c: high density lipoprotein cholesterol.

${ }^{a}$ Waist circumference $>88$ for women and $>102$ for men were defined as abdominal obesity. ${ }^{b}$ Systolic blood pressure $\geq 130$ or diastolic blood pressure $\geq 85$ was defined as unfavorable. ${ }^{\mathrm{d}} \mathrm{HDL}-\mathrm{C}<50$ for women and $<40$ for men were defined as unfavorable.

metabolic diseases such as obesity, type 2 diabetes and MetS. ${ }^{25-27}$ It has been suggested that these hormones induce increased release of S100B protein by adipocytes which consequently leads to elevated lipolysis. 5,28,29 The enhanced free fatty acids during lipolysis leads to increased TG level. ${ }^{30}$ However, further studies are needed to obtain definitive evidences « to link S100B to TG.

In the present study, the subjects with hypertension had higher levels of S100B. The finding was in agreement with earlier investigations. Higher serum S100B levels have been reported in hypertensive patients compared to controls. ${ }^{31}$ Cannon et al. have also indicated that subjects with higher concentrations of $\mathrm{S} 100 \mathrm{~B}$ had significantly higher carotid SBP than those with low levels of S100B. ${ }^{9}$ Further, Sherstnev et al. have indicated that serum levels of S100B can be used as possible predictors of arterial hypertension. ${ }^{32}$ Possibly, increased S100B level in hypertensive patients is an adaptive response to catecholamines enhancement in these subjects. ${ }^{33,34}$ It has been reported that catecholamine injection induces $\mathrm{S} 100 \mathrm{~B}$ mRNA and protein in myocardial tissue, ventricular myocytes and increased $\mathrm{S} 100 \mathrm{~B}$ in

Table 4 - Spearman's correlation of serum levels of S100 B protein with demographic, anthropometric and metabolic parameters

\begin{tabular}{lcc} 
& \multicolumn{2}{c}{ S100B } \\
\hline Age & Spearman's rho & $p$ value \\
Gender & -0.08 & 0.45 \\
BMI & 0.01 & 0.91 \\
Insulin & 0.15 & 0.17 \\
HOMA-IR & 0.02 & 0.82 \\
TC & 0.02 & 0.85 \\
LDL-c & 0.09 & 0.39 \\
\hline
\end{tabular}

BMI: body mass index; HOMA-IR: homeostatic model assessment- insulin resistance; TC: total cholesterol arterial tissues. ${ }^{35,36}$ However, the role of S100B in pressor responses to catecholamine stimulation is unclear.

In the current study, serum S100B level was not related to serum levels of FBG and HDL-c. Investigation in these topics is really scarce. In agreement with our findings, there was only one study by Refay et al addressing the relationship between S100B and these biomarkers. They have reported that serum S100B level was negatively correlated with serum HDL level but not with FBG in MetS patients. ${ }^{37}$ The negative correlation between S100B and HDL-c was also observed in the present study but it was statistically nonsignificant. This poor correlation could be attributed to MetS severity in the patients. In Refay et al study nearly half of the subjects met the full criteria for MetS.

Increased S100B level in MetS patients may elicit two important metabolic responses including promotion of inflammation and enhancement of blood pressure. In the adipose tissue, secretion of pro-inflammatory cytokines such as TNF- $\alpha$ from macrophages is known to be regulated by adipocyte derived S100B. ${ }^{3}$ Further, extracellular S100B, in higher concentrations, acts as an immunomodulatory compound where it stimulates expression of various proinflammatory cytokines. ${ }^{3}$ Besides, as mentioned earlier, increased release of S100B protein by adipocytes induces lipolysis which further leads to increased TG level and subsequently to atherosclerosis and hypertension. ${ }^{23,24}$ Thus, it is speculated that increased S100B levels could be considered as a key factor contributing in the pathogenesis of cardiovascular disorders in patients with MetS.

The most important limitation of the study was its crosssectional design. Thus, the directions of cause and effect could not be determined. Therefore, the association among variables must be interpreted with caution. The relatively small sample size was another limitation of the study and further larger studies are required to confirm these results. 


\section{CONCLUSIONS}

Findings from the current study indicate that there may be a link between S100B protein and the MetS. Abdominal obesity and adipose tissue mass determines serum S100B levels and predispose to development of MetS via upregulation of circulating TG and thus hypertension. Hence, it is speculated that increased S100B levels is possibly involved in the pathogenesis of cardiovascular disorders in patients with MetS.

\section{PROTECTION OF HUMANS AND ANIMALS}

The study was approved by the Ethical Committee of Tabriz University of Medical Sciences, Tabriz, Iran (Ref. no. TBZMED.REC.1394.345). The procedures followed the regulations established by the Clinical Research and Ethics

\section{REFERENCES}

1. Gonçalves CA, Leite MC, Guerra MC. Adipocytes as an important source of serum S100B and possible roles of this protein in adipose tissue. Cardiovasc Psychiatry Neurol. 2010;2010:790431.

2. Leite MC, Galland F, Brolese G, Guerra MC, Bortolotto JW, Freitas $R$, et al. A simple, sensitive and widely applicable ELISA for S100B: Methodological features of the measurement of this glial protein. J Neurosci Methods. 2008;169:93-9.

3. Fujiya A, Nagasaki H, Seino Y, Okawa T, Kato J, Fukami A, et al. The role of $\mathrm{S} 100 \mathrm{~B}$ in the interaction between adipocytes and macrophages. Obesity. 2014;22:371-9.

4. Buckman LB, Anderson-Baucum EK, Hasty AH, Ellacott KLj. Regulation of $\mathrm{S} 100 \mathrm{~B}$ in white adipose tissue by obesity in mice. Adipocyte. 2014;3:215-20.

5. Netto CB, Conte S, Leite MC, Pires C, Martins TL, Vidal P, et al. Serum $\mathrm{S} 100 \mathrm{~B}$ protein is increased in fasting rats. Arch Med Res. 2006;37:6836.

6. Steiner J, Walter M, Guest P, Myint AM, Schiltz K, Panteli B, et al. Elevated S100B levels in schizophrenia are associated with insulin resistance. Mol Psychiatry. 2010;15:3-4.

7. Holtkamp K, Bühren K, Ponath G, von Eiff C, Herpertz-Dahlmann $B$, Hebebrand $J$, et al. Serum levels of S100B are decreased in chronic starvation and normalize with weight gain. J Neural Transm. 2008;115:937-40.

8. Steiner J, Myint AM, Schiltz K, Westphal S, Bernstein HG, Walter M, et al. S100B serum levels in schizophrenia are presumably related to visceral obesity and insulin resistance. Cardiovasc Psychiatry Neurol. 2010;2010:480707.

9. Cannon JG, Sloan GJ, Webb RC, Cortez-Cooper M. Serum S100B is associated with stress, adiposity and elevated blood pressure. FASEB J. 2013;27:689.8.

10. Steiner J, Schiltz K, Walter M, Wunderlich MT, Keilhoff G, Brisch R, et al. S100B serum levels are closely correlated with body mass index: an important caveat in neuropsychiatric research. Psychoneuroendocrinol. 2010;35:321-4.

11. Bremer AA, Jialal I. Adipose tissue dysfunction in nascent metabolic syndrome. J Obes. 2013;2013:393192.

12. Abu-Farha M, Behbehani K, Elkum N. Comprehensive analysis of circulating adipokines and hsCRP association with cardiovascular disease risk factors and metabolic syndrome in Arabs. Cardiovasc Diabetol. 2014;13:76.

13. Grundy SM. Adipose tissue and metabolic syndrome: too much, too little or neither. Eur J Clin Invest. 2015;45:1209-17.

14. van de Woestijne AP, Monajemi H, Kalkhoven E, Visseren FL. Adipose tissue dysfunction and hypertriglyceridemia: mechanisms and management. Obes Rev. 2011;12:829-40.

15. Zou L, Wang W, Liu S, Zhao X, Lyv Y, Du C, et al. Spontaneous hypertension occurs with adipose tissue dysfunction in perilipin-1 null mice. Biochim Biophys Acta. 2016;1862:182-91.

16. Celikbilek A, Akyol L, Sabah S, Tanik N, Adam M, Celikbilek M, et al. $\mathrm{S} 100 \mathrm{~B}$ as a glial cell marker in diabetic peripheral neuropathy. Neurosci Lett. 2014;558:53-7.

17. Sathe K, Maetzler W, Lang JD, Mounsey RB, Fleckenstein C, Martin HL,
Committee and to the Helsinki Declaration of the World Medical Association.

\section{DATA CONFIDENTIALITY}

The authors declare having followed the protocols in use at their working center regarding patients' data publication. Informed consent was duly obtained from the patient.

\section{CONFLICTS OF INTEREST}

The authors declare no conflict of interests.

\section{FUNDING SOURCES}

This research received no specific grant from any funding agency in the public, commercial, or not-for-profit sectors.

et al. S100B is increased in Parkinson's disease and ablation protects against MPTP-induced toxicity through the RAGE and TNF- $\alpha$ pathway. Brain. 2012;135:3336-47.

18. Polyakova M, Sander C, Arelin K, Lampe L, Luck T, Luppa M, et al. First evidence for glial pathology in late life minor depression: S100B is increased in males with minor depression. Front Cell Neurosci. 2015;9:406.

19. Hov KR, Bolstad N, Idland AV, Zetterberg H, Blennow K, Chaudhry FA, et al. Cerebrospinal fluid S100B and Alzheimer's disease biomarkers in hip fracture patients with delirium. Dement Geriatr Cogn Dis Extra. 2017;7:374-85.

20. da Silva LG, Mottin CC, Souza DO, Portela LV, Braga CW, Vargas CB, et al. Serum S100B but not NSE levels are increased in morbidly obese individuals affected by obstructive sleep apnea-hypopnea syndrome. Obes Surg. 2008;18:993-9.

21. Riad E, Nasser M, Hussein MH, Toraih EA, Fawzy MS. Serum S100B: a possible biomarker for severity of obstructive sleep apnea. Egypt $J$ Chest Dis Tuberc. 2017;66:639-43.

22. O'Connell K, Thakore J, Dev KK. Levels of S100B are raised in female patients with schizophrenia. BMC Psychiatry. 2013;13:146.

23. Zhang Y, Reichel JM, Han C, Zuniga-Hertz JP, Cai D. Astrocytic process plasticity and IKKB/NF-KB in central control of blood glucose, blood pressure, and body weight. Cell Metab. 2017;25:1091-1102.e4.

24. Haimoto $H$, Kato K, Suzuki F, Nagura $H$. The ultrastructural changes of S-100 protein localization during lipolysis in adipocytes. An immunoelectron-microscopic study. Am J Pathol. 1985;121:185-91.

25. Godoy-Matos AF. The role of glucagon on type 2 diabetes at a glance. Diabetol Metab Syndr. 2014;6:91.

26. Fitzgerald PJ. Elevated norepinephrine may be an etiological factor in a wide range of diseases: age-related macular degeneration, systemic lupus erythematosus, atrial fibrillation, metabolic syndrome. Med Hypotheses. 2013;80:558-63.

27. Sen Y, Aygun D, Yilmaz E, Ayar A. Children and adolescents with obesity and the metabolic syndrome have high circulating cortisol levels. Neuro Endocrinol Lett. 2008;29:141-5.

28. Suzuki F, Kato K, Nakajima T. Hormonal regulation of adipose S-100 protein release. J Neurochem. 1984;43:1336-41.

29. Suzuki F, Kato K. Inhibition of adipose S-100 protein release by insulin. Biochim Biophys Acta. 1985;845:311-6.

30. Jung UJ, Choi MS. Obesity and its metabolic complications: the role of adipokines and the relationship between obesity, inflammation, insulin resistance, dyslipidemia and nonalcoholic fatty liver disease. Int $\mathrm{J} \mathrm{Mol}$ Sci. 2014;15:6184-223.

31. González-Quevedo A, García SG, Concepción OF, Freixas RS, Sotolongo LQ, Menéndez MC, et al. Increased serum S-100B and neuron specific enolase - Potential markers of early nervous system involvement in essential hypertension. Clin Biochem. 2011;44:154-9.

32. Sherstnev VV, Gruden' MA, Elistratova EI, Karlina VP, Kuznetsova AV, Ryzhova TV, et al. Molecular markers of arterial hypertension in patients with normotony, pre-hypertension and hypertension. Bull Exp Biol Med. 2015;158:604-6.

33. Liu R, Zhang Q, Luo Q, Qiao H, Wang P, Yu J, et al. Norepinephrine 
stimulation of alpha1D-adrenoceptor promotes proliferation of pulmonary artery smooth muscle cells via ERK-1/2 signaling. Int J Biochem Cell Biol. 2017;88:100-12.

34. Pichavaram P, Yin W, Evanson KW, Jaggar JH, Mancarella S. Elevated plasma catecholamines functionally compensate for the reduced myogenic tone in smooth muscle STIM1 knockout mice but with deleterious cardiac effects. Cardiovasc Res. 2018 (in press).

35. Tsoporis JN, Marks A, Kahn HJ, Butany JW, Liu PP, O'Hanlon D, et al. Inhibition of norepinephrine-induced cardiac hypertrophy in $s 100 \beta$ transgenic mice. J Clin Invest. 1998;102:1609-16.

36. Tsoporis JN, Overgaard CB, Izhar S, Parker TG. S100B modulates the hemodynamic response to norepinephrine stimulation. Am J Hypertens. 2009;22:1048-53.

37. El Refay AS, Ahmed HH, Hameed ERA, Kaairy S, Abdelsalam HM, Ali AEA. Potential activity of $S 100 B$ level towards metabolic syndrome in obese children. Sci Res J Pharm Biol Chem Sci. 2016;7:1136-41. 